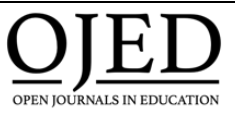

Volume 4, Issue 1 (2020), pp. 50-53

International Journal of

Entrepreneurship and Economic Issues

ISSN: 2616-0048 Print/ ISSN: 2631-231X Online

\title{
The Rebirth of the Eagle and Learning in the COVID 19 Pandemic: An International Student's Perspective
}

\author{
Muhammad Sharif Uddin \\ Morgan State University, USA
}

\begin{abstract}
COVID 19 has brought a new struggle in our lives throughout the world. Thousands of people are affected every day with the coronavirus, and this virus is still killing 1,000s of people. It has brought a new order of life for us with many changes. This current pandemic is also a message for everyone to look for alternatives in their daily lives for the sake of survival. Using the parable of the eagle, this paper examines the experiences of an international student how the epidemic has affected and changed his study.
\end{abstract}

Keywords: alternative, COVID 19, eagle, life, rebirth, survival.

\section{THE REBIRTH OF AN EAGLE}

I was born and grew up in a hilly area of a developing country named Bangladesh. When I was an elementary school student, there was no electricity in our area. We, the siblings, used to study at night together using one oil lamp inside the house. When it was the moonlit light, we came out to the yard and studied using the moon's light. The older adults of the community often came to us and wanted to hear stories from our books. 
They also shared various folk stories with us. Very often, I remember many of these motivational stories. The following story during the COVID 19 pandemic gives me more strength and inspiration.

It is a story about the eagle. An eagle usually lives $30-40$ years. But it can survive up to 70 years if it can take a rebirth itself. An eagle cannot fly at a particular age. Between 30-40 years of age, its feathers become thick and heavy and stuck with its chest. Additionally, its beak becomes long and bent; thus, it cannot prey any animal to eat. It that stage, the eagle needs to make a solid decision either to die without food or to take a rebirth through a painful and lengthy process.

For taking a rebirth, the eagle looks for a rock. When it finds a stone, it knocks its beak until it plucked out. Then the eagle waits to grow its new beak. As soon as its beak grows, the eagle pulls off its old feathers with the beak and waits for growing new feathers. Then, new feathers come out, and the eagle again starts its new life to prey and survive. This lengthy process takes four to five months, and the eagle passes that time even without food.

Reading online news in Reuter recently, this story again reminds me that we can lead our lives in an alternative way. The report was about a young girl in India. Sharma (2020) wrote in Reuters about a 15 years old poor girl, who rode a bicycle 745 miles carrying her father in the cycle's back. The grueling journey of Jyoti Kumari, saved her father's life while there was a lockdown due to the COVID 19 pandemic. While driving an autorickshaw in New Delhi to earn basic groceries, her father lost one of his legs in an accident. They ran out of money to pay rent, and even they had no food to eat due to the lockdown. Thus, Jyoti decided to leave New Delhi to save her disabled father's life. As there was no transportation, she used her bike to carry her father over seven days and reached their hometown in Bihar. They drank water and dry foods on their long journey.

\section{ALTERNATIVE FOR SURVIVAL}

Jyoti's journey and the rebirth of an eagle have a similarity with me. An eagle takes a resurrection experiencing a long and painful process. Throughout its 70-year life span, this eagle does not surrender to the situation. It is not hopeless. The eagle knows the process will be severely painful, but it wants to survive through it. Eventually, it achieves the rebirth through hard work and determination. Jyoti also did the same thing. A young girl knew that it was not easy to cycle hundreds of miles carrying a man. She was determined and wanted to survive herself and to save her 
father from the current COVID 19 pandemic. At last, she succeeded. She did not depend on others and did not wait if the government would help the poor people. She was determined to fight against a difficult situation.

I glean motivation from the above real stories to take alternative actions to survive. As an international student at a university in the United States, I live here without family. I am experiencing struggle for my academic career due to the pandemic. It started from the second week of March 2020 when we received an email from the President of the university that all classes were switched to online from the next day for two weeks. I had no experience in online courses and even no expertise in technology. Even my adjunct professor to whom I have two classes for that semester also has incompetency in technology that we experienced in his classes.

In that situation, I became hopeless and helpless as it was my last semester to complete the course works for doctoral studies. I emailed my professor, called over his cell phone several times, and texted him. Unfortunately, I got no reply. Then I contacted my course mates, and they also shared the same feeling as mine. I kept emailing and calling him over his cell phone. I contacted the department's chair, and she replied that we would be fine. The next week I got an email from my instructor, and he sent me an assignment for the following week. Every week I received an email from the instructor to submit assignments, and I followed those directions. Nonetheless, there was no communication other than getting instructions for the task and sending them to him.

By this time, I received another email from the University President that the rest of the semester will be online. My life became more stressful due to the campus closing. I prepared my dissertation proposal, and the dissertation committee approved it to move forward to a defense. The committee chair suggested that I wait and see what would happen to the campus due to the pandemic. The campus closing was protracted and continued through the end of the semester. My committee then suggested that I change my dissertation topic as there is uncertainty regarding the fall semester. If the campus goes online with remote instruction, I will be unable to ascertain the data to complete my dissertation. As a result, I have prepared a new proposal and have submitted it to my committee for their approval. My alternative actions are giving me the light of hope to complete my studies soon. 


\section{CONCLUSION}

Both of the stories stated above are not from the myth. We know that our lives are full of struggles, and we face challenges every day. We cannot surrender without fighting with reality. To be successful in our mission, we should have self-determination and self-motivation. Though I have used the word hopeless, I was scared that my study could not be completed. My determination has shown me the path that $I$ have to look for alternatives to go to my destination. The stories about the eagle that I enjoyed in my early life have provided a model for me to preserve despite the painful transformation to online learning.

\section{REFERENCES}

Sharma, S. (2020, May 27). 'I was determined', says girl who cycled injured dad across India. Reuters. https://www.reuters.com/article/us-healthcoronavirus-india-women-trfn/i-was-determined-says-girl-whocycled-injured-dad-across-india-idUSKBN2331WV

MUHAMMAD SHARIF UDDIN is a scholar in the Urban Educational Leadership Program at Morgan State University, USA. He also works as a graduate research assistant and as an adjunct faculty in the Department of Teacher Education at Morgan. He is a Fellow of International Leaders in Education Programs. His research interest is teacher education, critical pedagogy, and soka education. His email address is uddinsm@gmail.com 